\title{
The Impact of COVID-19 on the GCC Construction Industry
}

\author{
Tariq Umar, Kingston University, UK \\ (iD) https://orcid.org/0000-0002-1197-8181
}

\begin{abstract}
The Coronavirus pandemic has badly affected everyone on the earth. Apart from losing thousands of lives, businesses and individuals are going to be affected by the long-lasting financial effects due to an expected global recession. The impact of the financial crises can, however, be reduced if proper measured are put in place. This article aims to investigate the impact of Coronavirus on the construction industry in the Gulf Cooperation Council (GCC) member countries and provide recommendations to help the industry to sustain during this period of crisis. A qualitative research method involving face-to-face online interviews held with the construction industry professionals was adopted to achieve the aims and objectives of the research. Four main aspects of the impact on the construction industry are derived from analysis of interviews: 1) delays, 2) workforce management, 3) health and safety, and 4) legal issues. Recommendations are provided so that construction organizations in the GCC region can reduce the impact of Coronavirus on its businesses.
\end{abstract}

\section{KEYWORDS}

Construction Management, Construction Organizations, Construction Workers, Delay in Construction Projects, Health and Safety, Management, Project Management, Workforce Management

\section{INTRODUCTION}

The construction industry is not only contributing to the social and economic development of countries but is also a major industry around the world which provides jobs to the millions of peoples and contributes to countries and world economy. This fact has been confirmed in different studies, including Beven and the study conducted by Umar and Egbu (Bevan, 2010; Umar \& Egbu, 2018, p. 262). There is a direct role of the construction industry in delivering some of the United Nations Sustainable Development Goals including Goal 8: Decent Work and Economic Development, Goal 9: Industry Innovation and Infrastructures, and Goal 11: Sustainable Cities and Communities (Umar et al., 2020, p. 341). Similarly, the construction industry is further reported for a major portion of gross domestic product (GDP) in different countries, for instance, $6.10 \%$ in the United Kingdom, $5.50 \%$ in Japan, and 9.0\% in Oman (ONS, 2017; SHJ, 2017; NCSI, 2017). In the European Union (EU) member countries, the construction sector provides jobs to approximately 18 million peoples

\section{DOI: 10.4018/IJSSMET.20220301.oa1}

This article published as an Open Access article distributed under the terms of the Creative Commons Attribution License (http://creativecommons.org/licenses/by/4.0/) which permits unrestricted use, distribution, and production in any medium, provided the author of the original work and original publication source are properly credited. 
and contributes up to $9 \%$ of the total EU's GDP (EUCS, 2016). Overall, the construction industry employing $7 \%$ of the total world's workforce and accumulate $13 \%$ of the global GDP (Deloitte, 2017). As far as the GCC region is concerned, the industry appears to be growing. For instance, in Oman, it is expected that the value of the construction industry will grow to 6.88 Billion Omani Rial, which was 2.26 Billion Omani Rial in 2016 (Umar et al., 2018, p. 93). Moreover, the construction GDP in Oman is forecast to grow to $15.4 \%$ of the total GDP by 2026 . Overall, several researchers have reported that the construction growth rate is forecasted to be at peak in 2020. According to Oman's budget report, the spending on development projects was estimated at US\$ 3.12 billion, representing the amount paid during the year 2017, as the actual work progresses (TOM, 2017). Similarly, in 2016, the construction workforce in Oman was approximately 725,000, of which $92 \%$ were foreign workers (Umar, 2016, p. 68). The construction workforce thus, therefore, constitutes $16 \%$ of the total population of Oman. Similarly, the official statistics of Bahrain indicate that the total number of workforce in the construction industry is 174,912 representing $12 \%$ of the total population of Bahrain (LMRA, 2018). Statistics from the United Arab Emirates indicate that there are 65,000 construction organizations that employed more than 1,700,000 workers. These figures are based on the official data, which represents the workers who have a work permit/visa related to the construction profession. It is possible that the actual number of the workforce may be higher than this as there are workers in other sectors including materials, production, and supply chains that totally rely on the construction industry. Since, in most of the GCC countries, the economy is highly dependent on the oil and gas export, the GDP from the construction sector is therefore observed to be dropping as shown in Figure 1. Although there is an impact of the oil and gas prices on the construction industry, the overall construction projects in the GCC region that include buildings, infrastructures, and energy projects as shown in Figure 2, are growing.

The construction industry GCC countries, however, will not be able to avoid the adverse impacts of widespread COVID 19 although there are shutdowns and lockdowns in place to slow the spread of the coronavirus. The latest situation report issued on 27 March 2020 by the World Health Organization indicates that the number of infections and deaths from the Coronavirus is rapidly increasing (WHO, 2020). The situation is getting worse day by day (Our World in Data, 2020). Scientists and economic

Figure 1. Oman GDP from Construction (Trading Economic, 2020)

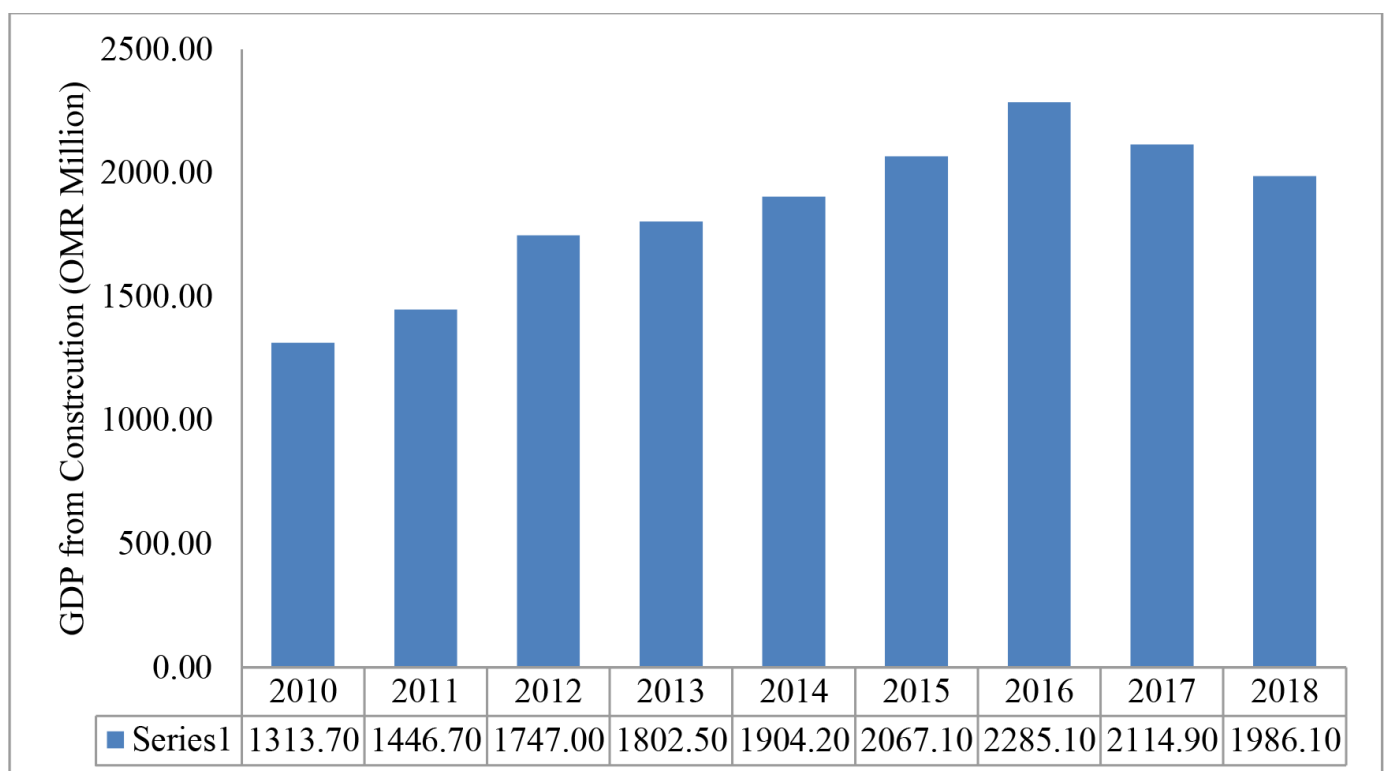


Figure 2. Comparison of Construction Contract Awarded in GCC Countries in 2019-2019 (Venture Onsite, 2019)

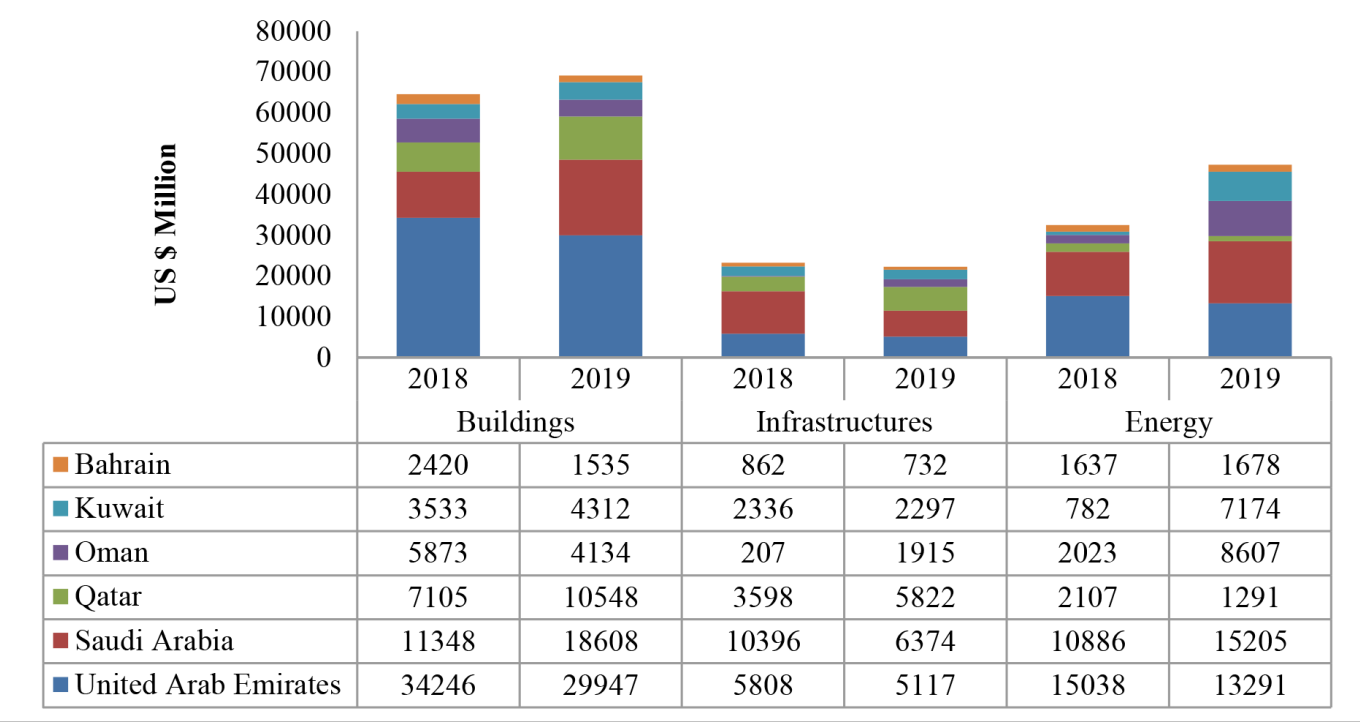

experts are warning of the global recession and financial losses that will be caused by the Coronavirus. For instance, a recent report published in Bloomberg indicates that COVID 19 can damage the global economy for around \$ 2.7 trillion (Bloomberg, 2020). While many countries imposed a closer on most of the industries to stop the spread of the virus, the construction sector is considered to remain open in most of the countries. This is due to the fact the most of the construction workers are daily wages, they are paid when they work. Similarly, the construction industry itself has a major role to play during this crisis. For instance, the construction of temporary quarantines and hospitals to cope with the situation arising from COVID 19 is only possible when there is no ban on the construction sector. Similarly, people around the world consider the construction industry and investment in infrastructure projects as a way towards recovery from the financial crises. A report published in the Asbury Park Press newspaper on $8^{\text {th }}$ April 2020, regarded construction workforce that can go to work without the same levels of contamination risks that other industries face as the work in construction does not lend itself to gatherings of people in confined locations (APA, 2020). Since, the current situation is worse than World War 2, even if the construction industry is allowed to operate during this period of the pandemic, there will be an impact on the industry. This research, therefore, aims to investigate the impact of the COVID 19 on the construction sector in GCC countries and aim to propose guidelines to help the industry to operate its business and maintain the required safety standards.

\section{RESEARCH METHODOLOGY}

There are a number of research approaches that can be adopted to achieve the aims and objectives of the research; however, as the current research is exploratory in nature and that the status of the COVID 19 is still not very clear, a qualitative research strategy was adopted to accomplish the aims and objectives of the research. A qualitative research approach was also adopted by Asdiou and Mokhtari (2019, p. 74) to propose an explanatory model identifying the determinants of the recourse to the CSR indicators and spotting the real motivation of companies to use them: for efficiency or concern for legitimacy towards stakeholders. Some researchers, however, prefer to adopt a mixed cross-sectional descriptive case study provided detailed data related to the topic of research is available ((Baporikar \& Randa, 2020, p. 7). Similarly, some researchers view that text documents can be used 
in multiple domains for obtaining and presenting the information for research ((Raja K. et al., 2020, p. 14). Gittins (1997, p. 17), noted that choosing the appropriate research methodology is important, as it determines the research methods to be adopted in the research. When choosing an appropriate research methodology the two main factors to be considered important as noted by Remenyi et al. (1998, p. 163). These factors are; (i) The specific research questions, and ii) the topic to be researched. While reviewing the research methods, Jobber (1991, p. 174) argued that it is wrong to claim that one method is superior in abstract terms, as every method has its strengths and limitations. While most of the researchers recommended involving both the research methods i.e. quantitative and qualitative to generalize the results of the research, however, considering the current situation and risk, it was decided not to adopt the quantitative approach (Bryman, 2016, p. 94; Opdenakker, 2006, p. 1). Even though, due to certain restrictions and lockdown throughout the world, the interviews held with the construction industry professionals were conducted using online resource zoom. Other resources were adopted in case Zoom was not working with any of the respondents. Using different online interview techniques is considered an approach of best practices by many researchers (Salmons, 2011, p, 169). Similarly, Janghorban et al. (2014, p. 24151) argued that online interview approaches have addressed all the challenges such as time, financial constraints, geographical dispersion, and physical mobility boundaries that are being faced during the face-to-face interview process. The advantages of using the SKYPE interview as a part of the qualitative research were best outlined by Lo Iacono et al. (2016, $\mathrm{p}, 1)$ in their research entitled "Skype as a Tool for Qualitative Research Interviews". SKYPE was, however, not used in this due to restriction imposed on SKYPE from the Omani government (TRA, 2015). Overall, the existing literature suggests that online interviews can be the best approach that can be adopted in the current situation of COVID 19.

To identify the potential respondents, messages were posted on LinkedIn and other social media describing the aims and objectives of the research and asking potential respondents to participate. Personal links, connections, and WhatsApp groups were also used to identify suitable candidates for this interview. These messages were posted for two weeks. The head of the construction organizations that are working in the GCC region was also requested through emails to nominate their staff to participate in this study. The list of construction organizations working in the GCC countries was obtained from the websites of the respective organizations which deal with the registration of construction companies. For instance, in Oman, the Tender Board of Oman and Oman Chamber of Commerce and Industry websites were used to identify the contractors (TBO, 2020, OCCI, 2020). Similarly, the construction organization's name and websites for the United Arab Emirates (UAE) were obtained from the UAE contractors Association website (UAE-CA, 2019). Since a large number of participants showed their interest to participate in the interview, screening criteria were imposed. For instance, the number of viewers of the post published on LinkedIn since the fourth day of its publishing was 1362 as shown in table 1 . Based on this criterion, only the respondents who have at least 15 years' experience with a minimum of 5 years in Oman or other GCC countries were selected. The minimum qualification for the respondents was set as a Bachelor's degree in a close and relevant discipline to construction. To include a global perspective of COVID 19 on the construction industry, two respondents were selected from outside the GCC region. Thus the minimum requirement of 5 years' experience was not applicable to such participants. After imposing the screening criteria, a total of 20 respondents from different GCC countries and two other countries as shown in Figure 3 were selected. Thus the total number of participants in this research was 22. A similar sample size was used in many studies of the same nature. For instance, Mason (2010, p.15) in his research entitled "Sample Size and Saturation in Ph.D. Studies Using Qualitative Interviews" reported the result of five hundred and sixty studies and noted that the most common size of the sample in these studies was 20. Similarly, a recent study which aimed to develop a framework to promote sustainability in higher education institutions also used a semi-structured interview approach in which the number of participants was also 20 (Umar, 2020, p. 10). 
Table 1. Number of Audience of Research Related Feed Posed on Linkedln

\begin{tabular}{|l|l|l|l|l|l|}
\hline \multicolumn{1}{|c|}{ Organization } & \multicolumn{1}{|c|}{ Number } & \multicolumn{1}{|c|}{ Job Title } & \multicolumn{1}{c|}{ Number } & \multicolumn{1}{c|}{ Location } & \multicolumn{1}{c|}{ Number } \\
\hline Sohar University & 7 & Civil Engineer & 86 & $\begin{array}{l}\text { London, United } \\
\text { Kingdom }\end{array}$ & 22 \\
\hline $\begin{array}{l}\text { A'Sharqiyah } \\
\text { University }\end{array}$ & 6 & Engineer & 50 & $\begin{array}{l}\text { Sydney, } \\
\text { Australia }\end{array}$ & 15 \\
\hline AECOM & 6 & University Professor & 48 & $\begin{array}{l}\text { Muscat } \\
\text { Governorate, } \\
\text { Oman }\end{array}$ & 12 \\
\hline $\begin{array}{l}\text { Cappa and D'Alberto } \\
\text { Plc }\end{array}$ & 6 & Construction Project & 37 & $\begin{array}{l}\text { Lahore, } \\
\text { Pakistan }\end{array}$ & 11 \\
\hline Atkins & 5 & Planner & $\begin{array}{l}\text { Bengaluru } \\
\text { Area, India }\end{array}$ & 9 \\
\hline BESIX & 4 & Project Manager & 27 & $\begin{array}{l}\text { Al Batinah } \\
\text { Region, Oman }\end{array}$ & 7 \\
\hline Network Rail & 3 & Construction & 18 & $\begin{array}{l}\text { Coventry, } \\
\text { United } \\
\text { Kingdom }\end{array}$ & 6 \\
\hline Alstom & 3 & Engineer & 18 & $\begin{array}{l}\text { Melbourne, } \\
\text { Australia }\end{array}$ & 5 \\
\hline Parsons Corporation & 3 & Business Strategist & 15 & $\begin{array}{l}\text { Leeds, United } \\
\text { Kingdom }\end{array}$ & 5 \\
\hline
\end{tabular}

Figure 3. Number of Participants from Different GCC Countries

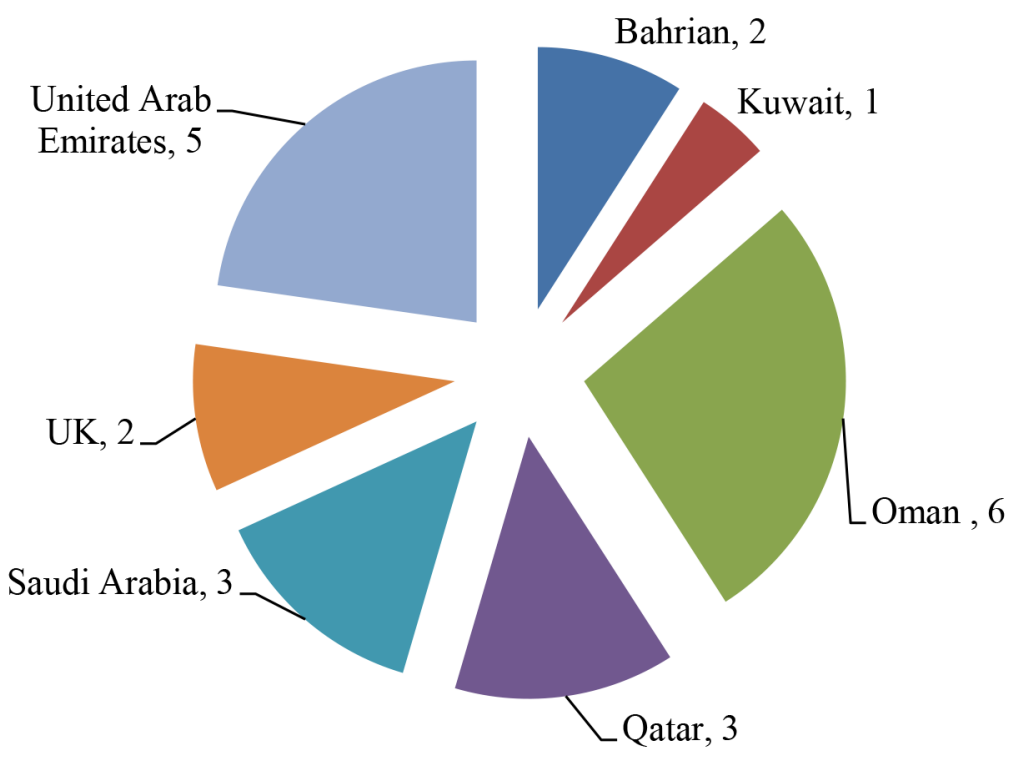


Interviewees were initially brief about the aims and objectives of the research. Each interview was then asked to highlight and discuss the main challenges that the construction industry or their organization is facing and what kind of actions they are taking to address these challenges. Interview questions were asked in the same way by keeping the sequence of questions similar in all interviews. Manual notes were made in each interview for recording their responses. Data was collected in a manner to which the content analysis technique can be applied easily. This includes coding the whole text/ script, identifying the themes with broader patterns of meaning, and defining and naming each of the themes (Graneheim and Lundman, 2004, p. 105; McIntosh and Morse, 2015, p. 233).

The next section presents the results and analysis of the study.

\section{RESULTS AND DISCUSSION}

Considering the scope of the results and discussion section, and based on the parameters of the impact of COVID 19 on the construction industry, the results and discussion section is divided into four subsections. Each section provides an insight into a specific area that resulted from the interviews. The first section discusses the delays of construction projects and highlights its possible economic impact.

\subsection{Delays in Construction Projects}

The research conducted by Assaf \& Al-Hejji (2006, p. 349) observed that only $30 \%$ of the construction projects in Saudi Arabia complete on time while the remaining $70 \%$ are delayed. Similarly, the National Audit Office report in the UK, quoting the data before the year 2000, shows that $70 \%$ of the government construction project delay (NAO, 2003). Research conducted in Saudi Arabia shows that on average, the contraction project delay amounted to $39 \%$ of the contractual time in the Kingdom (Elawi et al., 2016, p. 1402; Abdelhadi et al., 2019, p. 329). Another study conducted in Iran also noted that the average delay is the construction projects in Iran can be up to $40 \%$ of the actual contract time (Heravi and Mohammadian, 2019, p. 1). Similarly, Ruqaishi and Bashir (2015, p, 50) noted that from 2012 to 2015 , only $62 \%$ out of 40 construction projects in Oman were completed on time. In the construction industry in the United Arab Emirates which constitutes 14\% of the country's GDP, 50\% of the construction projects experience delays and cost overruns (Faridi and ElSayegh 2006, p. 1167; Motaleb and Kishk 2010, p. 1449). Some of the important projects in the United Arab Emirates such as the Dubai metro project also experienced a 5 years delay and $85 \%$ increase in cost from the estimated schedule and budget (Johnson and Babu, 2018, p. 1; CIOB, 2015). Of course, this delay estimate is in the normal situation where there was no pandemic like the one we are facing at the moment.

All interviewees agreed that COVID 19 will result in a significant delay in construction projects in the region. One of the interviewees from Oman noted that based on the government instruction adopted from the high-level committee that monitors the COVID 19 in Oman, we have been asked to reduce the workers by $50 \%$. Such a reduction of manpower will have a higher impact on the delay, which can be greater than the percentage of the reduction of workers. The closure of the borders of the GCC countries was also viewed as a potential factor by the interviewers that will contribute towards the delay of these projects. Some interviewees mentioned the restriction of movement from one city to another city as a key contributor to the project's delays. There are some cities in the GCC region which have imposed a curfew to avoid the spread of the COVID 19. The closure of the borders and other restrictions on movement results in disruption of the supply chain and thus the required materials cannot be reached to the site on time. Delay in materials delivery was recognized as one of the main causes of the delay in construction projects in Kazakhstan's construction projects (Hossain et al., 2019, p. 1).

While all the steps that the governments are taking are important in relation to control the virus, the construction industry is not exceptional and therefore expected to bear the consequences of COVID 19 and suffer from the delay of the projects. It is expected that CVID 19 will heavily impact the world economy and it is possible that the world will face another recession, which could be greater 
than the 2018 recession. To estimate the possible economic impact of the delay of the construction projects in the GCC region due to COVID 19, interviewees discussed different possible aspects of such impact, however, they emphasized that a true impact on the economy can only be measured once the virus is controlled, work resumed and all the required statistics are available. Some studies, however, provide a detailed cost of delay to different types of projects considering different reasons for the delay. While based on the budget of the construction project, it can be classified as a small, medium, or large construction project. A report developed by the Texas Transportation Institute indicates that a medium construction project cost US\$10,000 per day of delay (TTI, 2011). A more relevant study that looked into the cost of delay in the public construction projects in Qatar noted that the cost of the delay is approximately $25 \%$ of the contract price (Senouci et al., 2016, p. 368). Thus if it is assumed that the GCC construction project values will be the same as of 2019 (= US\$ 144,644 Million), the cost of delay can be equal to US $\$ 36,161$ Million. The key solution that interviewees have suggested is to utilize the workers and keep working on shifts. The interviewees were in their opinion that such a schedule of work will help to keep a good pace of work and will allow keeping all the workers on the job.

\subsection{Workforce Management}

The study conducted by Meduri and Srinivasa Rao D. (2020, p. 76) reveals a good relationship between competencies, job performance, and job satisfaction as some of the important elements to increase the productivity of the workers. Some researchers also viewed trust as another important element that has a high influence on workers' performance (Kumar \& Pradhan, 2020, p. 36). Similarly, some other studies which evaluated the implication of HRM on a business, its relationship to the Theory of Constraints (TOC), and the ways in which these concepts can aid a business in reaching its main objective, found that effective human resource management is important to achieve the organizational goals (Galli, 2019, p. 21; (Anjum et al., 2019, p. 52). All these factors however cannot be achieved by effective workforce management. Effective workforce management in this crisis period becomes more important than the normal situation.

The workforce management has a number of dimensions, however; all the participants considered that the safety and health factors should be given due importance during this pandemic time. The safety, health, and environment are therefore covered in a separate section in this paper. This section considers two important elements of workforce management i.e. a) social factor, b) Work Management.

The construction workers in all GCC countries are foreigners, thus they normally stay in the accommodation provided by their organization. In most cases, these workers are paid when they work. The current situation as confirmed by most of the interviewees, however, reveals the most of these workers will be unpaid during this period of the pandemic. For instance, a respondent United Arab Emirates highlighted that one of the most prominent land development company (Emaar) in Dubai has suspended its construction projects and has cut the salaries at certain levels (MEED, 2020). The interviewees agreed that most of the construction workers don't have large saving and their survival being unpaid for a longer period is not possible. It is therefore important that the construction industry keep continue to avoid such unemployment. Many countries allow the construction industry to operate during this period provided that safety measures are in place. For instance, Pakistan, which is a developing country, has announced an attractive package to support construction activities and has given the status of industry to construction. The Prime Minister in his speech indicated that the incentivized package for the construction industry is to increase employment opportunities in the country in the wake of the coronavirus outbreak (PMO, 2020). Similarly, the interviewee from the UK pointed out that the UK government allowed construction activities to continue, the number of workers in different projects is, however, reduced. He further pointed out that the workers who will lose their job will be able to get the benefit from the government package under which the worker while staying at home, will be paid $80 \%$ of his/her wages. A similar package is also introduced by the Building and Construction Authority of Singapore for Built Environment sector firms. Under this 
package, the who lost their jobs due to Corona will be paid $75 \%$ of their wages in April 2020, while they are also eligible for $25 \%$ of the wages for the next eight months (BCA, 2020). Similarly, the State Bank in Pakistan has introduced a new refinance scheme for businesses to avoid layoff of workers. Under this scheme, the government is aiming to provide loans to the businesses on soft terms so that they can sustain their business as they can retain their workers (SBP, 2020).

The respondents from the GCC region confirmed that at the moment, there is such a package from the government that could support the industry of the workers. The best option for construction organizations is to keep the minimum allowable operation at construction sites and engage the workers as much as possible. If the construction organizations are not working in the shift, then they need to start working in shift and utilize half of the workers in the first shift and half of them in the second shift. Working in the shift is also one of the solutions emphasize by Safe Work Australia to minimize the risk from COVID-19 and to protect workers in building and construction (SWA, 2020). If work in shifts is not possible, or the organizations are already working in the shits, but they reduced the number of workers to comply with the government instruction, then the organizations need to develop some consensus with it workers and try to engaged and keep them working even on a reduced salary or reducing the number of working days to support all the workers. The interviewee from Saudi Arabia argued that losing the workers is even not in the interest of the organizations. The COVID 19 pandemic will ultimately end in few months, but if the organizations lost many of its workers, rehiring foreign workers will then again take significant time and thus the work of the companies will suffer. One of the interviewees argued that the government's role in the current situation is crucial. Large organizations normally have good financial resources and can sustain for a longer period, however, small and medium organizations have fewer financial resources at their disposal (Umar et al., 2018, p. 93; Masi et al, 2014, p. 385). Apart from a package to support the construction organizations, the speedy process of the pending payment is also important for construction organizations to sustain during this hard period of time and support its employees.

\subsection{Health, Safety, and Environment}

The health and safety of the construction workers in the GCC were one of the main concerns of all the participants. There are several studies that reveal that safety and health in construction get the least importance in many countries. Organizations remain reluctant to spend money on issues that don't arise on a regular basis. The situation over safety and health in the construction industry is not at a satisfactory level (Umar et al., 2019, p. 137; Ganji, 2016, p, 221; ITUC, 2014; SM, 2018). Maintaining proper safety and health and avoiding the spread of COVID 19 required further Personal Proactive Equipment and measures. The World Health Organization recommends the use of masks, sanitizer, and recommends social distances. Social distancing is also the main part of the guidelines developed by the Scottish government for the construction industry (The Scottish Government, 2020). Similarly, the Associated General Contractors (AGC) of America also recommends washing the hand frequently for at least 20 seconds with soap, coving mouth and nose with a tissue when coughing and sneezing, and cleaning and disinfecting the areas which are frequently touched by hands or in frequent use (AGC, 2020). All the interviewees agreed that it is possible to maintain the required standards and avoid the spread of the virus. Although, most of them were agreed that construction is a physically demanding job, in which most of the time, workers are required to work closer (Umar and Egbu, 2020, p. 49). As shown in Figure 3, the workers are trying to put the formwork in place and thus they are very close to each other. Thus in some situations considering the nature of construction work, it is not really possible to maintain the recommended social distance. The interviewees, however, suggested that where the social distance seems to be compromised, such tasks must not be undertaken during this period of the pandemic. While, as shown in Figure 4, the workers are in an open environment, however, the risk of infection could be greater when these workers will be in their rooms or on the bus. As noted in the above section, most of the workers reside in the company provided accommodations, normally more than one worker in a room. In some cases, the accommodations are 
way from the work area and thus the workers are transported on a bus to workplaces. In such situations, the chances of the infection could be higher. One of the interviewees, however, noted that they are now transporting 50\% less workers in these buses. He further stated that they are regularly cleaning and disinfecting the accommodation area to avoid the spread of the virus. Similarly, the interviewee from Qatar pointed out the Public Authority of Work (PAW) in Qatar along with the Ministry of Administrative Development, Labour, and Social Affairs has started large inspection operations that aim to protect workers from COVID 19. The press release issued on $7^{\text {th }}$ April 2020 describes that the public Authority of Work in Qatar regularly inspects the workplaces and accommodation and issue necessary guidelines to reduce the risk associated with the coronavirus (PAW, 2020). The Authority also confirms that they have established a better accommodation facility with a total area of 142,724 square meters and all the arrangement complies with the standards of International Organization for Standardization (ISO: 22000, 2018). An interviewee from the Petroleum Development in Oman (PDO) stated that his organization has developed intensive guidelines to cope with COVID 19 to ensure the safety of all staff and contractors and to curb the spread of the virus. In this regard the PDO medical team screens all the employees traveling to operations areas on a daily basis (PDO, 2020). The interviewee from the UK stated that they are strictly following the Construction Leadership Council guidelines that are aligned with the Public Health England (PHE) and as per current instructions, we don't allow work where the minimum distance of $2 \mathrm{~m}$ cannot be maintained (CLC, 2020; PHE, 2020). An interviewee from Oman highlighted the use and importance of posters and signboards to promote safety and health guidelines among workers at the workplace. In this regard, the Department of Health in Australia has developed a number of posters related to COVID 19 that aim to provide awareness and guidelines for workers. These posters are available in different languages, free, and ready to print and place at workplaces (Department of health, 2020). The interviewee from the United Arab Emirates mentioned that they are monitoring workers' health indicators such as fever and flu on a daily basis. Another interviewee pointed out the lack of protective supplies in the market. One of the interviewees from Qatar pointed out that due to a surprising situation, clarity on some aspects of the PPE such as mask is still needed. While all interviewees agreed that health and safety are still a challenge, however, they confirmed that there is no positive case in their organizations neither they have not hear about any particular case that is from the construction industry. The key areas which interviewees recommended to avoid the spread of COVID 19 were:

Figure 4. Problems is Maintaining Social Distance at Construction Site

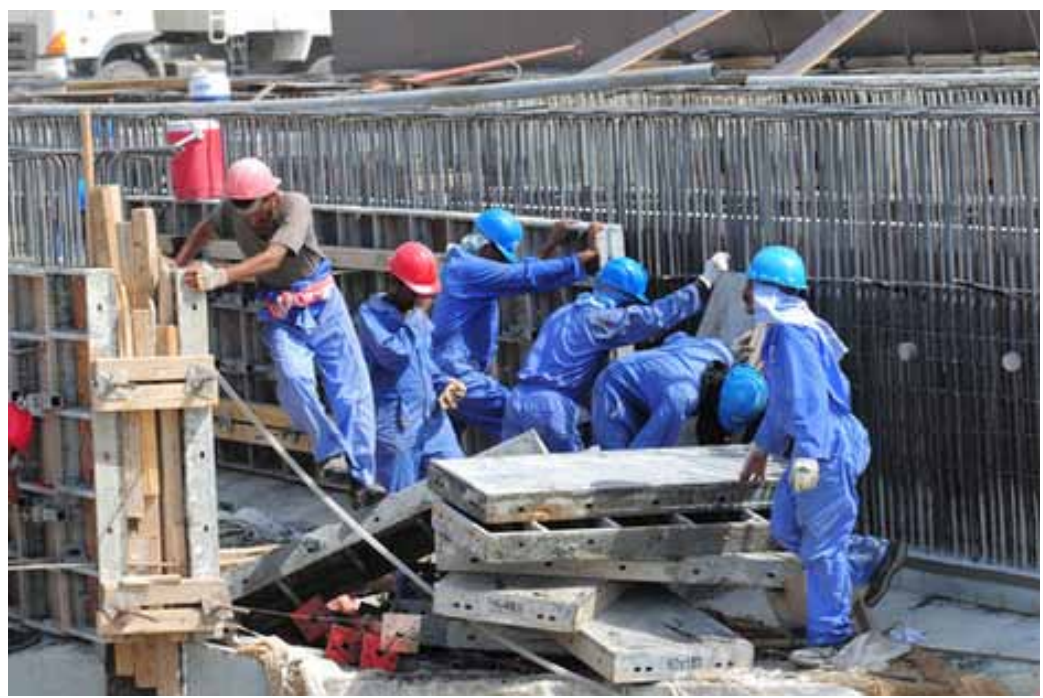


1. Ensuring social distancing at the workplace and at accommodation by appointing a responsible inspector on-site to make sure your workers are following the rules for physical distancing.

2. Checking the workers' temperature and other symptoms such as cough and flu on a regular basis

3. Ensuring the PPE for all workers

4. Briefing workers and safety inspectors on a daily basis

5. Cleaning and disinfecting workplace and accommodation are regular intervals

6. Avoid sharing of PEE

7. Restricting workers to workplace and accommodation

8. Postpone non-essential training for workers and provide safety and work-related guidelines through telephone calls and messages

9. Provide signboards and posters at the workplace and accommodation to promote safety awareness related to COVID 19 among construction workers

10. Use technological tools such as drones and CCTV to monitor the situation at the workplace and ensure physical distance compliance

11. Compliance with the government instructions

\subsection{Legal Issues}

The legal issues that will be arising from COVID 19 can be best understood by the recent lawsuit of \$20 trillion filed in the United States against China (Business Today, 2020). Similarly, an Egyptian lawyer also demanded China to pay $\$ 10$ trillion in coronavirus damages (Arab News, 2020). While there is clear evidence now that COVID 19 is creating legal issues among the countries, it will develop legal disputes among the businesses and this construction is not an exception. One of the main reasons which have an adverse impact on the time and cost of the construction projects is the legal disputes arise due to the litigious nature of the industry (Saseendran et al., 2020, p. 452). The unexpected volume of claims and disputes negatively impact the construction industry business. All the construction projects are executed through a contract but in most cases, these contracts are not easy to comprehend even by professionals (Iyer et al., 2008, p. 174). From a general perspective, COVID 19 is going to result in a variety of legal disputes however, the one which will affect the construction business environment, will be arising from construction project contracts. Of course, as identified by many researchers, the delay disputes will be on the top. For instance, a recent study conducted by Assaf et al. (2019, p. 1) in Saudi Arabia on the causes of claims and disputes reveals that most significant contributors to claims and disputes are; variations in quantities due to new requirements from the client $(=74 \%)$, the delay caused by the contractor $(=74 \%)$, variation orders due to new requirements from the client $(=78 \%)$, design errors or omissions $(=72 \%)$, and inconsistencies in the drawings and specifications $(=70 \%)$. Similarly, Another study which investigated the causes of delay in construction projects in Oman reported that contractual issues, workforce, materials, coordination between construction parties, and external factors are the main factors which cause delay to construction projects in Oman (Umar, 2018, p. 121). All the interviewees agreed that there will be a significant number of legal disputes in construction projects in the GCC region that will arise from COVID 19. The most common dispute will be related to the delay of projects. Interviewees suggested that such disputes need to be resolve among the clients and contractors to avoid further delays. Interviewees were in the consensus that COVID 19 as an act of God if both clients and contractors process the delay claims professionally and ethically, then there is no need to go to a court of law. The interviewees noted that there is a possibility that contractors may make false claims taking the shadow of COVID 19. An interviewee from Qatar pointed out that such false claims can be easily traced from the progress report submitted to the client or consultant and can be verified from the schedule of work that the contractor submitted. Another interviewee from Oman suggested that making an arbitrary committee that has a member from the client, consultant and contractor could be helpful to screen such claims. The interviewee from the UK pointed out that any engineers involve in a false 
claim can be subject to the Institution of Civil Engineers (ICE) code of professional conduct. The ICE code of professional conduct is applicable to all engineers registered as Chartered or Incorporated engineers or registered as a member of the ICE (ICE, 2017). Although, all the interviewees agreed that construction contracts, in different jurisdictions, may differ from each other but there is always a clause or provision of force majeure in many contracts. A force majeure clause that is included in many contracts is related to the occurrence of an event that is outside the reasonable control of a party prevented from performing its contractual obligations (Construction Management Guide, 2012). The judgment in Lebeaupin vs Crispin (1920) defines war, inundations, and epidemics, as causes of force majeure (Lebeaupin vs Crispin (1920). All the interviewees were in the opinion that COVID 19 is expected to be considered under the force majeure clause. Most of the interviewees noted that for construction organizations it is important to review all active contracts, identify provisions that may assist in the current situation, and consider what action needs to be taken. It is also important to issue notices to the second party and, if needed, instigate reminders if further developments will impact the delay or cost implications. The construction organizations are also required to comply with the obligations to avoid and mitigate the consequences of any delay or disruption. Similarly, the main or principal contractors need to ensure to receive information that possible delay issues from the sub-contractors. Maintaining an updated record of the workforce that is working and that is not working for each day during this pandemic period is important to support a claim at a later stage. Such a record for sub-contractors will also be useful. Interviewees agreed that conducting regular risk meetings with all parties is important to identify and agree upon the reasonable measures that can be taken to litigate delay or disruption. It is important for all contractors to take proactive steps to estimate if critical materials or supplies for incorporation in the works are being or are likely to be delayed. Maintaining an audit trail to prove that all possible steps are being taken to mitigate such delays is also important in the current situation. The interviewees also argued that it is important for the construction organizations to review all the contracts that are in the negotiable stage and ensure to incorporate new clauses that can cover the situation being arisen from COVID 19.

The next section provides the conclusion of the paper.

\section{DISCUSSION AND CONCLUSION}

Whenever there is a pandemic on the earth, it has a long-lasting impact on the societies and the economy of the world. While the current pandemic is still going one, some earlier studies have considered the impact of the previous pandemic and have suggested that if there will be another pandemic, what will be the possible impact. For instance, the study conducted by Meltzer et al. (1999, p. 659), noted the possible impact of new influenza in the United States and argued that the estimated economic impact would be US\$71.3 to $\$ 166.5$ billion, excluding disruptions to commerce and society. Similarly, Smith et al. (2009, p. 339) estimated the economy-wide impact of pandemic influenza on the UK and noted that the costs related to illness alone ranged between $0.5 \%$ and $1.0 \%$ of gross domestic product. The macroeconomic impact of pandemic influenza estimated from models of the United Kingdom, France, Belgium, and the Netherlands suggests GDP losses from the disease of approximately 0.5-2\% (Keogh-Brown et al., 2010, p. 543). While the current pandemic is a global pandemic, the economic loss will be huge and even it can be estimated accurately as the pandemic is still going one. Similarly, nobody on the earth has even imagen that the world can be hit by such crises. The COVID 19 has locked the whole world and has directly or indirectly affected all the individuals. While the crisis is still going on, it is important to take some steps that can reduce the impact of the crises on the business and individuals. This article presented the results of semistructured interviews held with the construction industry professional to gauge the impact of the COVID 19 on the GCC construction industry and propose recommendations so that the work on construction can be kept on at construction sites. All the interviewees were in agreement that it is important not to put a ban on the construction operations as it will help to reduce the economic impact of the local and global economy. The key aspects of the impact that are arising from the COVID 19 were explored in the paper 
were related to the delays of the construction projects, effective management of workforce, health and safety issues, and legal aspects. The main factors that could cause delays to the construction projects in the whole GCC region are the closer of the borders, reducing the number of workers at construction sites, and disturbance in the supply chain management. All these factors are, however, part of the government actions which aim to reduce the spread of the virus. The delay in construction projects, however, can be reduced if the industry is allowed to keep its operation going on. Some countries in the GCC region have already ready allowed the construction companies to continue their operations with a reduced number of workers. While reducing the number of workers will results in lower progress however, construction managers need to manage their workers and progress and for that, working is shift is the best solution. If a construction company is already working in the shift, and the government has asked the company to reduce the number of workers, the company also needs to manage such situations wisely considering social aspects. It is not recommended that the organization only engages the workforce who is allowed by the government and terminate the remaining workers. This can create social problems but can also create a shortage of workers for the construction organizations when the pandemic will end. They will require to follow again the long procedure to hire and bring new workers for their projects which is a time-consuming process and thus will affect the progress of company projects. All these issues can be tackled by engaging all the workers even though with a reduced pay or reducing the number of days. For instance, the company is allowed to reduce the number of workers by $50 \%$ at construction sites, thus the company needs to utilize $50 \%$ of the workers in the first half of the month and reaming $50 \%$ in the second half of the month. In this way, the company retains all its workers and none of the workers become jobless. At least they have work for 15 days in a month. Government support will be important to help businesses to sustain during this period. Since most of the infrastructure projects in the GCC region are government-funded, the release of any pending payment and processing of other payment on priority will be a sign of relief for construction companies involved in the projects. Similarly, the government can also support the construction sector by providing loans on softer terms and conditions. It is also important, that the construction organizations ensure the safety and health of its workers and take the necessary steps to avoid the spread of the virus. In this regard, it is necessary to implement the WHO guidelines that include the daily temperature check with a thermal thermometer, ensure physical distances at the workplace, provide hand sanitizer, and disinfect the workplace at frequent intervals. The status of occupational safety and health in the region is always questioned by many researchers, however, the results of this research indicate that some organizations in the region are doing a very good job to ensure the health and safety of their workers and avoid the spread of the virus. It is anticipated that the number of legal disputes in the construction industry will be increased due to the impact of COVID 19. The interviewees recommended that there needs to be a mechanism to investigate all the claims that will be arising from the current pandemic situation. The formation of a committee that has members from all the stakeholders of the construction projects will be helpful to process all such claims in a time-bound manner. Such a committee should have access to the progress reports and the schedule of the work of the project that was submitted to the consultant or the client. The interviewees agreed that construction managers need to play an active role, they need to understand the current provisions of the contracts and ensure they gather all the required information to support their claims. Such information can be helpful to resolve any dispute mutually and avoid the matter to reach the court of law which can further affect the progress of the project. The sustainability of the construction industry is important so that it can play it vital role to reduce the impact of COVID 19 globally. The research presented in the paper has considered the GCC construction industry and explored the possible impact and solutions. It is anticipated that most of the factors that are affecting the GCC construction industry can be applicable to the construction in other regions and thus the findings of this paper can be valid and useful for the whole construction industry.

\section{FUNDING AGENCY}

Open Access Funding for this article has been provided by IGI Global. 


\section{REFERENCES}

Abdelhadi, Y., Dulaimi, M. F., \& Bajracharya, A. (2019). Factors influencing the selection of delay analysis methods in construction projects in UAE. International Journal of Construction Management, 19(4), 329-340. doi:10.1080/15623599.2018.1435155

AGC (Associated General Contractors of America), the Construction Association. (2020). Coronavirus - COVID-19 Basics. Associated General Contractors of America, the Construction Association. agc.org/ coronavirus/covid-19-basics

Anjum, A., Ming, X., \& Puig, L. C. M. (2019). Analysis of Strategic Human Resource Management Practices in Small and Medium Enterprises of South Asia. International Journal of Service Science, Management, Engineering, and Technology, 10(1), 44-61. doi:10.4018/IJSSMET.2019010104

APA (Asbury Park Press). (2020). Can infrastructure investment lead us in time of crisis - again? Asbury Park Press. https://amp-app-com.cdn.ampproject.org/c/s/amp.app.com/amp/2964185001

Arab News. (2020). Egyptian lawyer demands China pay $\$ 10$ trillion in coronavirus damages. Arab News. https://www.arabnews.com/node/1654456/middle-east

Asdiou, A., \& Mokhtari, B. (2019). The Indicators of the Corporate Social Responsibility. International Journal of Service Science, Management, Engineering, and Technology, 10(1), 62-76. doi:10.4018/IJSSMET.2019010105

Assaf, S., Hassanain, M. A., Abdallah, A., Sayed, A. M., \& Alshahrani, A. (2019). Significant causes of claims and disputes in construction projects in Saudi Arabia. Built Environment Project and Asset Management, 9(5), 597-615. Advance online publication. doi:10.1108/BEPAM-09-2018-0113

Assaf, S. A., \& Al-Hejji, S. (2006). Causes of delay in large construction projects. International Journal of Project Management, 24(4), 349-357. doi:10.1016/j.ijproman.2005.11.010

Baporikar, N., \& Randa, I. O. (2020). Organizational Design for Performance Management in State-Owned Enterprises. International Journal of Service Science, Management, Engineering, and Technology, 11(4), 1-25. doi:10.4018/IJSSMET.2020100101

BCA (Building and Construction Authority). (2020). Support measures for Built Environment sector firms. Building and Construction Authority. https://www1.bca.gov.sg/COVID-19/support-measures-for-builtenvironment-sector-firms/

Beven, R. (2010). Global Construction 2020 and Global Opportunities. Pinsent Masons. http://www.tecniberia. es/documentos/GlobalConstruction2020andGlobalOpportunities.pdf

Bloomberg. (2020). Coronavirus Could Cost the Global Economy \$2.7 Trillion. Here's How. Bloomberg. https:// www.bloomberg.com/graphics/2020-coronavirus-pandemic-global-economic-risk/

Bryman, A. (2016). Social research methods. Oxford university press.

Business Today. (2020). \$20 trillion lawsuit against China! US group says coronavirus is bioweapon. Business Today. https://www.businesstoday.in/current/world/usd-20-trillion-lawsuit-against-china-us-group-sayscoronavirus-bioweapon/story/399071.html

CIOB (The Chartered Institute of Building). (2015). The century's most troublesome projects. The Chartered Institute of Building. https://www.constructionmanagermagazine.com/international/centurys-most-troublesomeconstruction-projects/

CLC (Construction Leadership Council). (2020). Coronavirus Update - Updated Site Operating Procedures. Construction Leadership Council. http://www.constructionleadershipcouncil.co.uk/news/coronavirus-updateupdated-site-operating-procedures/

Construction Management Guide. (2012). Force majeure - the devil is in the detail. Construction Management Guide. http://www.cmguide.org/archives/2853

Deloitte. (2017). Deloitte GCC Powers of Construction 2017, If it's fundable it's feasible. Deloitte. https:// www2.deloitte.com/content/dam/Deloitte/xe/Documents/realestate/construction/gccpowersofconstruction/ me_construction_gccpoc2017.pdf 
Department of Health. (2020). We have publications on different health topics for you to access. Filter by topic, publication type, audience, condition and disease. Department of Health, Government of Australia. https://www. health.gov.au/resources/publications?f\%5B0\%5D=field_publication_type\%3A2181

Elawi, G. S. A., Algahtany, M., \& Kashiwagi, D. (2016). Owners' perspective of factors contributing to project delay: Case studies of road and bridge projects in Saudi Arabia. Procedia Engineering, 145, 1402-1409. doi:10.1016/j.proeng.2016.04.176

EUCS (European Union Construction Sector). (2016). Brochure - The European construction sector - A global partner - 2016 edition. European Union. http://ec.europa.eu/DocsRoom/documents/15866/attachments/1/ translations

Faridi, A. S., \& El-Sayegh, S. M. (2006). Significant factors causing delay in the UAE construction industry. Construction Management and Economics, 24(11), 1167-1176. doi:10.1080/01446190600827033

Galli, B. J. (2019). Critical Thinking of Human Resources in the Goal. International Journal of Service Science, Management, Engineering, and Technology, 10(1), 19-29. doi:10.4018/IJSSMET.2019010102

Ganji, S. K. (2016). Leveraging the World Cup: Mega sporting events, human rights risk, and worker welfare reform in Qatar. Journal on Migration and Human Security, 4(4), 221-259. doi:10.1177/233150241600400403

Gittins, R. (1997). Qualitative Research: An Investigation into Methods and Concepts in Qualitative Research. School of Informatics, University of Wales Bangor.

Graneheim, U. H., \& Lundman, B. (2004, February). Qualitative content analysis in nursing research: Concepts, procedures and measures to achieve trustworthiness. Nurse Education Today, 24(2), 105-112. doi:10.1016/j. nedt.2003.10.001 PMID:14769454

Heravi, G., \& Mohammadian, M. (2019). Investigating cost overruns and delay in urban construction projects in Iran. International Journal of Construction Management. doi:10.1080/15623599.2019.1601394

Hossain, M. A., Raiymbekov, D., Nadeem, A., \& Kim, J. R. (2019). Delay causes in Kazakhstan's construction projects and remedial measures. International Journal of Construction Management. doi:10.1080/15623599.2 019.1647635

ICE (Institution of Civil Engineers). (2017). ICE Code of Professional Conduct. Institution of Civil Engineers. https://www.ice.org.uk/ICEDevelopmentWebPortal/media/Documents/About\%20Us/ice-code-of-professionalconduct.pdf

ISO (International Organization for Standardization, 22000). (2018). ISO 22000 Food Safety Management. International Organization for Standardization. https://www.iso.org/iso-22000-food-safety-management.html

ITUC (International Trade Union Confederation). (2014). The Case against Qatar, Host of the FIFA 2022 World Cup. ITUC. https://www.ituc-csi.org/IMG/pdf/the_case_against_qatar_en_web170314.pdf

Iyer, K. C., Chaphalkar, N. B., \& Joshi, G. A. (2008). Understanding time delay disputes in construction contracts. International Journal of Project Management, 26(2), 174-184. doi:10.1016/j.ijproman.2007.05.002

Janghorban, R., Roudsari, R. L., \& Taghipour, A. (2014). Skype interviewing: The new generation of online synchronous interview in qualitative research. International Journal of Qualitative Studies on Health and Wellbeing, 9(1), 24152. doi:10.3402/qhw.v9.24152 PMID:24746247

Jobber, D. (1991). Choosing A Survey Method in Management Research. In The Management Research Handbook. Routledge.

Johnson, R. M., \& Babu, R. I. I. (2018). Time and cost overruns in the UAE construction industry: a critical analysis. International Journal of Construction Management. doi:10.1080/15623599.2018.1484864

Keogh-Brown, M. R., Smith, R. D., Edmunds, J. W., \& Beutels, P. (2010). The macroeconomic impact of pandemic influenza: Estimates from models of the United Kingdom, France, Belgium and The Netherlands. The European Journal of Health Economics, 11(6), 543-554. doi:10.1007/s10198-009-0210-1 PMID:19997956

Kumar, V., \& Pradhan, P. (2020). Trust Management. International Journal of Service Science, Management, Engineering, and Technology, 11(4), 26-44. doi:10.4018/IJSSMET.2020100102 
Lebeaupin vs. Richard Crispin and Company (1920) 2 K.B. 714, 702.

LMRA (Labour Market Regulatory Authority). (2018). Bahrain Labour Market Indicators. Labour Market Regulatory Authority. http://blmi.lmra.bh/2010/12/mi_data.xml

Lo Iacono, V., Symonds, P., \& Brown, D. H. (2016). Skype as a tool for qualitative research interviews. Sociological Research Online, 21(2), 1-15. doi:10.5153/sro.3952

Masi, D., Cagno, E., \& Micheli, G. J. L. (2014). Developing, implementing and evaluating OSH interventions in SMEs: A pilot, exploratory study. International Journal of Occupational Safety and Ergonomics, 20(3), 385-405. doi:10.1080/10803548.2014.11077059 PMID:25189744

Mason, M. (2010, August). Sample size and saturation in $\mathrm{PhD}$ studies using qualitative interviews. In Forum qualitative Sozialforschung/Forum: qualitative social research (Vol. 11, No. 3, pp. 1 - 19). 10.17169/fqs-11.3.1428

McIntosh, M. J., \& Morse, J. M. (2015). Situating and constructing diversity in semi-structured interviews. Global Qualitative Nursing Research, 2. doi:10.1177/2333393615597674 PMID:28462313

Meduri, Y., \& Srinivasa Rao, D. (2020). Humanitarian Efficiency and Role of Relief Workers. International Journal of Service Science, Management, Engineering, and Technology, 11(4), 72-86. doi:10.4018/ IJSSMET.2020100105

MEED. (2020). Middle East Business Intelligence. Emaar Dubai suspends projects and cuts salaries. MEED. https://www.meed.com/emaar-dubai-suspends-projects-and-cuts-salaries

Meltzer, M. I., Cox, N. J., \& Fukuda, K. (1999). The economic impact of pandemic influenza in the United States: Priorities for intervention. Emerging Infectious Diseases, 5(5), 659-671. doi:10.3201/eid0505.990507 PMID:10511522

Motaleb, O., \& Kishk, M. (2010). An investigation into causes and effects of construction delays in UAE. Proceedings 26th Annual ARCOM Conference, 1149-1157. https://www.arcom.ac.uk/-docs/proceedings/ar20101149-1157_Motaleb_and_Kishk.pdf

NAO (National Audit Office). (2003). Construction Performance. National Audit Office. https://www.nao.org. uk/report/pfi-construction-performance/

NCSI (National Centre for Statistics and Information). (2017). Monthly Statistical Bulletin, January, 2017. National Centre for Statistics and Information.

OCCI (Oman Chamber of Commerce and Industry). (2020). Industrial Directory. Oman Chamber of Commerce and Industry. https://chamberoman.om/economic-information/occi-directory/industrial-directory/

ONS (Office for National Statistics). (2017). Construction Statistics: Number 18, 2017 Edition. Office for National Statistics. https://www.ons.gov.uk/businessindustryandtrade/constructionindustry/articles/constructionstatistics/ number182017edition

Opdenakker, R. (2006, September). Advantages and disadvantages of four interview techniques in qualitative research. In Forum Qualitative Sozialforschung/Forum: Qualitative Social Research (Vol. 7, No. 4, pp. 1 - 13). $10.17169 /$ fqs-7.4.175

Our World in Data. (2020). Coronavirus Disease (COVID-19) - Statistics and Research. Our World in Data. https://ourworldindata.org/coronavirus

PAW (The Public Authority of Work). (2020). Ashghal Launches Intense Inspection Campaign at Workplaces and Labor Accommodations. The Public Authority of Work. http://www.ashghal.gov.qa/en/MediaHub/News/ Pages/Ashghal-Launches-Intense-Inspection-Campaign-at-Workplaces-and-Labor-Accommodations.aspx

PDO (Petroleum Development Oman). (2020). PDO and Combatting Coronavirus (COVID-19). Petroleum Development Oman. https://www.pdo.co.om/hseforcontractors/Pages/awareness.aspx

PHE (The Public Health of England). (2020). Coronavirus (COVID-19): what you need to do. The Public Health of England. https://www.gov.uk/government/collections/coronavirus-covid-19-list-of-guidance

PMO (Prime Minister Office, Pakistan). (2020). PM announces package for construction industry. Prime Minister Office. http://www.radio.gov.pk/03-04-2020/pm-announces-package-for-construction-industry 
Raja, K., \& Kanagavalli, V. R. (2020). An Efficient Methodology for Resolving Uncertain Spatial References in Text Documents. International Journal of Service Science, Management, Engineering, and Technology, 11(3), 1-17. doi:10.4018/IJSSMET.2020070101

Remenyi, D., Williams, B., Money, A., \& Swartz, E. (1998). Doing research in business and management: an introduction to process and method. Sage. doi:10.4135/9781446280416

Ruqaishi, M., \& Bashir, H. A. (2015). Causes of delay in construction projects in the oil and gas industry in the gulf cooperation council countries: A case study. Journal of Management Engineering, 31(3), 05014017. doi:10.1061/(ASCE)ME.1943-5479.0000248

Salmons, J. (2011). Cases in online interview research. Sage Publications.

Saseendran, A., Bigelow, B. F., Rybkowski, Z. K., \& Jourdan, D. E. (2020). Disputes in Construction: Evaluation of Contractual Effects of ConsensusDOCS. Journal of Legal Affairs and Dispute Resolution in Engineering and Construction, 12(2), 04520008. doi:10.1061/(ASCE)LA.1943-4170.0000377

SBP (State Bank of Pakistan). (2020). SBP introduced new refinance scheme to avoid layoff of workers. State Bank of Pakistan. https://www.sbp.org.pk/press/2020/Pr-10-Apr-20.pdf

Senouci, A., Ismail, A., \& Eldin, N. (2016). Time delay and cost overrun in Qatari public construction projects. Procedia Engineering, 164, 368-375. doi:10.1016/j.proeng.2016.11.632

SHJ (Statistical Handbook of Japan). (2017). Manufacturing and Construction. Statistical Handbook of Japan, 2017. Statistics Bureau, Ministry of Internal Affairs and Communication. http://www.stat.go.jp/english/data/ handbook/pdf/2017all.pdf

SM (Safety Media). (2018). Key Middle East Safety Statistics. SM. https://safetymedia.co.uk/me/middle-eastsafetystatistics/

Smith, R. D., Keogh-Brown, M. R., Barnett, T., \& Tait, J. (2009). The economy-wide impact of pandemic influenza on the UK: A computable general equilibrium modelling experiment. BMJ (Clinical Research Ed.), 339(nov19 1), b4571. doi:10.1136/bmj.b4571 PMID:19926697

TBO (Tender Board of Oman). (2020). Registered Companies. Tender Board of Oman. https://etendering. tenderboard.gov.om/product/ReportAction?eventFlag=RegVendorPublic

The Scottish Government. (2020). Coronavirus (COVID-19): construction sector guidance. The Scottish Government. https://www.gov.scot/publications/coronavirus-covid-19-construction-sector-guidance/pages/ overview/

TOM. (2017). Oman budget: Despite austerity, Oman committed to investment. Time of Oman. https:// timesofoman.com/article/99741/Oman/Government/Oman-budget:-Despiteausterity-Oman-committed-toinvestment

TRA (Telecommunication Regulatory Authority). (2015). Telecommunications Regulatory Act \& Amendments 2015. Telecommunication Regulatory Authority. https://www.tra.gov.om/legal-framework/the-telecom-act/26the-telecom-act

Trading Economic. (2020). Oman GDP From Construction. Trading Economic. https://tradingeconomics.com/ oman/gdp-from-construction

TTI (Texas Transportation Institute). (2011). Assessing the Costs Attributed to Project Delays. The Texas A\&M University System, College Station. https:/ftp.dot.state.tx.us/pub/txdot-info/fed/project-delay-summary.pdf

UAE-CA (UAE Contractors Association). (2019). Member list. UAE Contractors Association. http:// uaecontractors.org/members_list_pdf/MEMBER_LIST_2017.pdf

Umar, T. (2016). Cost of accidents in the construction industry of Oman. Proceedings of the Institution of Civil Engineers. Municipal Engineer, 170(2), 68-73. doi:10.1680/jmuen.16.00032

Umar, T. (2018). Causes of delay in construction projects in Oman. Middle East Journal of Management, 5(2), 121-136. doi:10.1504/MEJM.2018.091132 
Umar, T. (2020). An Integrated Sustainability Management Approach for Universities. In Proceedings of the Institution of Civil Engineers-Engineering Sustainability (pp. 1-12). Thomas Telford Ltd. doi:10.1680/ jensu.19.00014

Umar, T., \& Egbu, C. (2018). Perceptions on safety climate: a case study in the Omani construction industry. Proceedings of the Institution of Civil Engineers-Management, Procurement and Law, 1-13. doi:10.1680/ jmapl.18.00001

Umar, T., \& Egbu, C. (2020, March). Heat stress, a hidden cause of accidents in construction. Proceedings of the Institution of Civil Engineers. Municipal Engineer, 173(1), 49-60. doi:10.1680/jmuen.18.00004

Umar, T., Egbu, C., Honnurvali, M. S., Saidani, M., \& Al-Bayati, A. J. (2019). Briefing: Status of occupational safety and health in GCC construction. Proceedings of the Institution of Civil Engineers-Management, Procurement and Law, 172(4), 137-141.

Umar, T., Egbu, C., Ofori, G., Honnurvali, M. S., Saidani, M., Shibani, A., Opoku, A., Gupta, N., \& Goh, K. (2020). UAE's commitment towards UN Sustainable Development Goals. Proceedings of the Institution of Civil Engineers. Engineering Sustainability, 173(7), 325-343. doi:10.1680/jensu.19.00036

Umar, T., Egbu, C., Ofori, G., Honnurvali, M. S., Saidani, M., Shibani, A., Opoku, A., Gupta, N., \& Goh, K. (2020, February). UAE's Commitment Towards UN Sustainable Development Goals. In Proceedings of the Institution of Civil Engineers-Engineering Sustainability (pp. 1-18). Thomas Telford Ltd. doi:10.1680/jensu.19.00036

Umar, T., Egbu, C., Wamuzir, S., \& Honnurvali, M. S. (2018). Occupational Safety and Health Regulations in Oman. Proceedings of the Institution of Civil Engineers-Management, Procurement and Law, 171(3), 93-99. doi:10.1680/jmapl.18.00007

Venture Onsite. (2019). GCC Construction Market. Venture Onsite. https://hardwareandtools-middle-east. ae.messefrankfurt.com/content/dam/messefrankfurt-dubai/Hardwareandtools-middle-east/2019/documents/ HTME\%202019\%20GCC\%20Construction\%20Market\%20Report_01.3.pdf

WHO (World Health Organization). (2020). Coronavirus disease 2019 (COVID-19): situation report, 67. World Health Organization. https://apps.who.int/iris/bitstream/handle/10665/331613/nCoVsitrep27Mar2020-eng.pdf

Tariq Umar has completed his Ph.D. degree in Construction Management from London South Bank University, UK and registered as a Chartered Civil Engineer (CEng)/ International Professional Engineer (IntPE) with Engineering Council UK. He has more than 9 years of academic research and teaching experience and has published several research articles in the area of construction management, renewable energy, engineering sustainability, construction materials, and waste and resource management. Additionally, he has served in the civil engineering industry for 6 years. He is an approved mentor of the Institution of Civil Engineers (ICE, UK) and helping graduate engineers to become professionally qualified engineers. He is also serving as member of the editorial board/advisor for a number of journals. His research interest includes but not limited to, Construction Management, Safety and Health, Engineering Sustainability, Construction Materials, Renewable Energy, and Waste and Resources Management. 